\title{
A 485 year record of atmospheric chloride, nitrate and sulfate: results of chemical analysis of ice cores from Dyer Plateau, Antarctic Peninsula
}

\author{
Jihong Cole Dai, lonnie G. Thompson and Ellen Mosley-Thompson \\ Byrd Polar Research Center, The Ohio State University, Columbus, OH 4.3210, U.S.A.
}

\begin{abstract}
Detailed ionic analyses of Dyer Plateau snow show that major soluble impurities in snow consist of sodium $\left(\mathrm{Na}^{+}\right)$, chloride $(\mathrm{Cl})$, nitrate $\left(\mathrm{NO}_{3}\right)$, sulfate $\left(\mathrm{SO}_{4}{ }^{2}\right)$, and acidity $\left(\mathrm{H}^{+}\right)$. The ratios of $\mathrm{Na}^{+}$to $\mathrm{Cl}$ concentrations are close to that of sea water, indicating little or no fractionation of sea-salt aerosols. The analyses of core sections from three sites along a $10 \mathrm{~km}$ transect show that local spatial variation of snow chemistry in this area is minimal and that temporal (decadal, inter-annual and sub-annual) variations in snow chemistry are very well preserved.

Anion analyses of the upper $181 \mathrm{~m}$ section of two $235 \mathrm{~m}$ ice cores yield a data set of 485 years (1505-1989) of annual snow accumulation and fluxes of $\mathrm{Cl}^{-}, \mathrm{NO}_{3}{ }^{-}$and nonsea-salt (nss) $\mathrm{SO}_{4}{ }^{2}$. No significant long-term trends are observed in any of the anion fluxes. This is consistent with other Antarctic ice-core records showing no significant anthropogenic atmospheric pollution in the high southern latitudes. Linear regression analysis shows that $\mathrm{Cl}^{-}$flux is independent of snow-accumulation rate. Significant positive correlations are found between accumulation rate and both $\mathrm{NO}_{3}^{-}$flux and background nss- $\mathrm{SO}_{4}{ }^{2-}$ flux. These results suggest that dry deposition is primarily responsible for air-to-ground $\mathrm{Cl}^{-}$flux while wet deposition dominates the $\mathrm{NO}_{3}$ and nss$\mathrm{SO}_{4}{ }^{2-}$ flux $\geq 90 \%$ and $\geq 75 \%$, respectively). The nss- $\mathrm{SO}_{4}{ }^{2}$ fluxes provide a chronology of explosive volcanic emissions reaching the Antarctic region for the past 485 years.
\end{abstract}

\section{INTRODUCTION}

Ice cores from Antarctica and other permanent ice bodies in the world provide abundant information on paleoclimate and the history of atmospheric composition (Delmas, 1992). In Antarctica, concentrations of soluble chemical constituents in snow reflect the composition of atmospheric aerosols (Legrand and Delmas, 1984; Wagenbach and others, 1988). However, in order to reconstruct paleoatmospheric history using ice-core results, the relationships between the amounts of the chemical species found in snow and their atmospheric concentrations must be investigated carefully. Ideally, quantitative transfer functions should be established to properly infer atmospheric conditions from results of ice-core analyses. Furthermore, deposition processes and the atmospheric history of aerosol constituents may vary spatially (Shaw, 1989); therefore, interpretation of ice-core results may require locationspecific transfer functions.

During the period 1988-90, a suite of ice cores was collected on Dyer Plateau (Thompson and others, 1994), located along the crest of the Antarctic Peninsula approximately halfway between the northern tip and the southern base (Fig. 1). The core collection on Dyer Plateau is part of an ongoing effort to characterize the glaciologic and the climatic regime across the middle of the Antarctic Peninsula (Dolleman Island to Dyer Plateau to Alexander Island). Future long-term ice-core

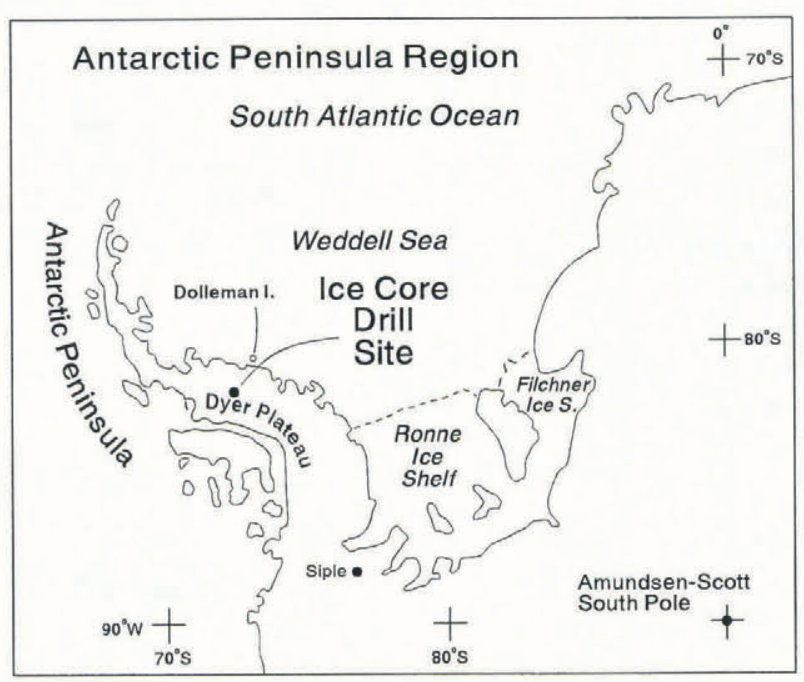

Fig. 1. Map of the Antarctic Peninsula region showing the location of Dyer Plateau and other ice-core locations mentioned in this work (Dolleman Island and Siple Station).

records from this area may provide a crucial link between climatic histories from ice cores drilled in Antarctica and the climatic records from South America (Thompson and others, 1985).

Presented here are the results of chemical analyses of Dyer Plateau ice-core samples. The goal of this study is 
two-fold: (1) to characterize the natural spatial variability of the snow chemical composition and (2) to assess the utility of ice-core records from this location as a tool for reconstructing the paleoenvironmental history of this region. To examine the spatial variability of snow chemistry, sections of ice cores covering the crest area of the plateau were analyzed and the results of the chemical analyses are compared. The 485 year history of annual net accumulation and anion fluxes was obtained from analyses of the upper $181 \mathrm{~m}$ section of two $235 \mathrm{~m}$ cores.

\section{EXPERIMENTAL PROGEDURES}

\section{Ice-core location and recovery}

Dyer Plateau is located in the middle of the Antarctic Peninsula (Fig. 1). The crest of the plateau $70^{\circ} 40^{\prime} \mathrm{S}$, $64^{\circ} 52^{\prime} \mathrm{W}$, elevation $2002 \mathrm{ma.s.l}$.) is approximately $150 \mathrm{~km}$ west of Dolleman Island which lies along the west coast of the Weddell Sea (Fig. 1). In the 1988/89 and 1989/90 austral-summer field seasons, several cores of various lengths $(50-235 \mathrm{~m})$ were drilled at three sites along a $10 \mathrm{~km}$ east-west transect across the ice divide. All cores were drilled and handled in the field with stringent contamination-control procedures Mulvaney and Peel, 1988); and, after being transported frozen to ice-core processing facilities, the cores were stored at $-30^{\circ} \mathrm{C}$ prior to the analyses.

\section{Scope of study and analysis}

To study snow chemical composition and its spatial variability, one core from each of the three sites was selected. Samples from one continuous section $4-5 \mathrm{~m}$ in length) in each core were analyzed for ionic concentrations, and the oxygen-isotope ratios $\left(\delta^{18} \mathrm{O}\right)$ were measured on all of these cores to assist in dating. Table 1 provides information on the core sections analyzed, the sampling scheme and the dating of the sections.

Continuous measurements of anion concentrations have been conducted on the top $112 \mathrm{~m}$ (dated AD 1761$1989)$ of a $235 \mathrm{~m}$ core (C1) and on part (107-181 m, AD 1505-1784) of another $235 \mathrm{~m}$ core (C2) drilled $1 \mathrm{~m}$ away from core $\mathrm{C} 1$. The relatively high annual snowaccumulation rate of $450 \mathrm{~mm}$ w.e. allowed analyses of 6 15 samples per year. A total of 3850 samples was analyzed to produce the 485 year record.

\section{Sample preparation and analytical procedures}

All snow and ice samples were decontaminated prior to chemical analysis. A pre-cleaned band-saw was used to decontaminate firn cores by removing a $20 \mathrm{~mm}$ thick layer from all exposed surfaces. Below the firn/ice transition which occurs between 55 and $60 \mathrm{~m}$, ice samples were washed with ultra-pure deionized water. A procedural blank (frozen ultra-pure deionized water) was included with each batch of samples prepared for analysis. Before washing and melting, all sample preparation was conducted on a clean-air bench in a cold $\left(-10^{\circ} \mathrm{C}\right)$ work room. The decontaminated samples were melted at room temperature in sealed plastic (poly-
Table 1. The three drill sites on Dyer Plateau are located along a $10 \mathrm{~km}$ east-west transect across the ice divide. One section of each of the three cores was selected to correspond to the decade 1950 60, based on preliminary depth-age estimates. Dating was accomplished by counting $\delta^{18} O$ and $\mathrm{SO}_{4}{ }^{2-}$ cycles from the top of each core. Non-sea-salt sulfate calculation is according to Equation (1) and the $\mathrm{Na}^{+}$ $\mathrm{SO}_{4}{ }^{2-}$ ratio in sea water (see text)

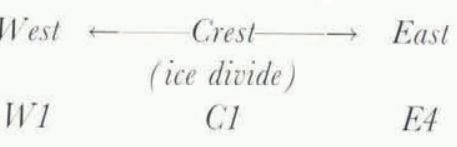

$\begin{array}{lccc}\text { Depth }(\mathrm{m}) & 27.5-32.0 & 25.0-30.0 & 27.0-32.0 \\ \text { No. of samples } & 65 & 57 & 67 \\ \text { No. of years } & 6.0 & 7.2 & 5.7\end{array}$

$\begin{array}{lccc}\text { Date } & 1951-56 & 1953-59 & 1958-63 \\ \text { Dating method } & \delta^{18} \mathrm{O} & \delta^{18} \mathrm{O} \text { and } \mathrm{SO}_{4}{ }^{2} & \delta^{18} \mathrm{O}\end{array}$

Annual accum- $\quad 55 \quad 40 \quad 56$ ulation

(cm w.e.)

$\begin{array}{lccc} & \text { Average concentrations }\left(\mu \mathrm{equ} \mathrm{I}{ }^{-1}\right. & \\ \mathrm{Cl} & 1.48 & 1.40 & 1.09 \\ \mathrm{NO}_{3}{ }^{2} & 0.52^{*} & 0.38 & 0.44 \\ \mathrm{SO}_{4}{ }^{2} & 0.65 & 0.65 & 0.75 \\ \mathrm{Na}^{+} & 1.00 & 1.10 & 0.88 \\ \mathrm{~K}^{+} & 0.10 & 0.09 & 0.15 \\ \mathrm{nss} \mathrm{SO}_{4}{ }^{2} & 0.53 & 0.52 & 0.64 \\ \mathrm{Na}^{+} / \mathrm{Cl} & 0.74 & 0.82 & 0.83 \\ \delta^{\#} & 0.16 & 0.15 & 0.13 \\ \end{array}$

* 57 uncontaminated samples 8 of the 65 samples were contaminated by laboratory standard solutions during analysis and therefore not included).

\# Standard deviation.

ethylene) containers and were analyzed in a class-100 clean-room laboratory immediately after melting.

All cation and anion measurements were made by ion chromatography. The analytical procedures for the measurements of anions $\mathrm{Cl}^{-}, \mathrm{NO}_{3}$ and $\mathrm{SO}_{4}{ }^{2}$ ) have been described elsewhere (Mosley-Thompson and others, 1991). For the cations, a combination of Dionex FAS SEP CATION I and II columns was used with an eluant of $3 \mathrm{mM}$ DAP diaminoproponic acid) in $10 \mathrm{mM} \mathrm{HCl}$. A cation micromembrane suppressor column (Dionex) was regenerated continuously with a solution of $10 \mathrm{mM} \mathrm{KOH}$. The column combination and a column-switching technique allow simultaneous determination of sodium $\left(\mathrm{Na}^{+}\right)$, ammonium $\left(\mathrm{NH}_{4}^{+}\right)$, potassium $\left(\mathrm{K}^{+}\right)$, magnesium $\left(\mathrm{Mg}^{2+}\right)$ and calcium $\left(\mathrm{Ca}^{2+}\right)$ ions. However, the $\mathrm{Mg}^{2+}$ and $\mathrm{Ca}^{2+}$ concentrations of most samples were below the detection limits of this analytical method $\left(\approx 20 \mu \mathrm{gl}^{-1}\right)$. As discussed by other authors (Saigne and others, 1987; Mulvaney and Peel, 1988), the laboratory measurement of $\mathrm{NH}_{4}^{+}$in Antarctic snow is subject to serious contamination from the 
dissolution of $\mathrm{NH}_{3}$ in ambient air. Although an effort was made to control the exposure of melting samples to the laboratory atmosphere, the $\mathrm{NH}_{4}{ }^{+}$data are not considered contamination-free and are therefore not reported here.

For typical concentrations $\left(0.2-2.5 \mu \mathrm{equl}{ }^{-1}\right)$ of $\mathrm{Na}^{+}$, $\mathrm{Cl}, \mathrm{NO}_{3}{ }^{-}$and $\mathrm{SO}_{4}{ }^{2}$, the analytical error of measurements is $10 \%$ or less, with negligible procedural blank values. Due to extremely low concentrations $\left(\approx 0.1 \mu \mathrm{equ}^{-1}\right), \mathrm{K}^{+}$ measurements carry an error of about $100 \%$.

\section{RESULTS}

\section{Dating}

Annual cycles of $\mathrm{SO}_{4}{ }^{2-}$ concentrations and those of $\delta^{18} \mathrm{O}$ are very well preserved along the entire depth of all cores (Fig. 2). Therefore, all cores were dated by counting annual cycles in continuous $\delta^{18} \mathrm{O}$ and/or $\mathrm{SO}_{4}{ }^{2}$ concentration profiles. A "year" is defined as the firn or ice layer between two adjacent minima in $\delta^{18} \mathrm{O}$ or $\mathrm{SO}_{4}{ }^{2}$ concentration. The thickness of that layer is converted to water equivalent using density measurements along the core and represents net accumulation in that year.

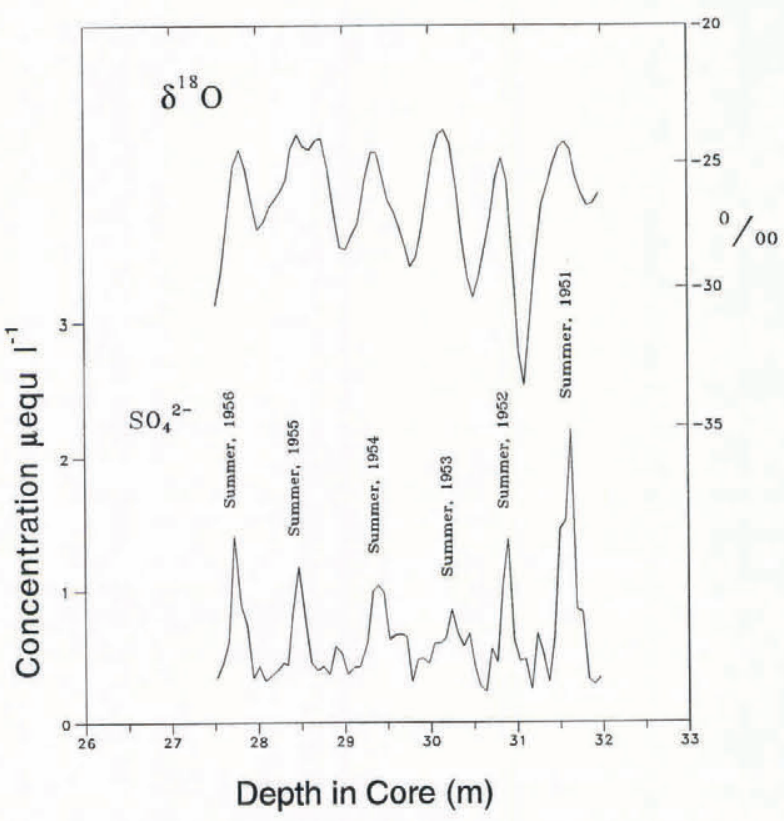

Fig. 2. An example of the well-preserved seasonal variations of $\delta^{18} \mathrm{O}$ and $\mathrm{SO}_{4}{ }^{2-}$ in a section of a Dyer core (core W1; see Table 1 for details). The core is dated by counting $\delta^{18} \mathrm{O}$ cycles from the lop of the core, assuming that $\delta^{18} \mathrm{O}$ and $\mathrm{SO}_{4}{ }^{2-}$ maxima occur in the austral summer.

For the most recent 200 years, the dating errors are negligible, as indicated by the accurate dates for several known volcanic horizons (e.g. Tambora in AD 1816).

No analyses were made on either core C1 or core C2 below $181 \mathrm{~m}$ due to very poor core quality. Core C2 suffers from poor core quality (probable loss of ice during drilling) between 112 and $130 \mathrm{~m}$ (AD 1706-63). In core C2 the dating below $112 \mathrm{~m}$ was refined by comparing prominent $\mathrm{SO}_{4}{ }^{2-}$ horizons, believed to be volcanic, with those in a well-dated core drilled in 1985 at Siple Station (Fig. 1) at the base of the Antarctic Peninsula (Mosley-Thompson and others, 1991). Prominent volcanic events in the Dyer cores match those in the Siple Station core very well (Thompson and others, 1994). The accumulated dating uncertainty at 485 years is estimated to be \pm 3 a.

\section{Layer-thinning correction}

As with all ice cores, annual snow layers at Dyer thin as they are buried under successive new snowfalls and are stretched due to the outflow of ice from the ice divide. A complementary geophysical study at the Dyer ice-core sites provides information about the characteristics of the ice flow (personal communication from C. Raymond and others, 1994). This allows the annual layer thicknesses or net annual accumulation to be corrected for thinning at depth (Thompson and others, 1994), as shown in Figure 3 . In the $112-130 \mathrm{~m}$ section of core $\mathrm{C} 2$ where significant core loss was encountered, it was difficult to determine accurately annual layer thicknesses. Data for this section are not shown in Figure 3; instead, a linear extrapolation of the thinning curve for this section (1706-63) is presented and subsequently used in the annual-flux calculation (see Figure 3 and caption).

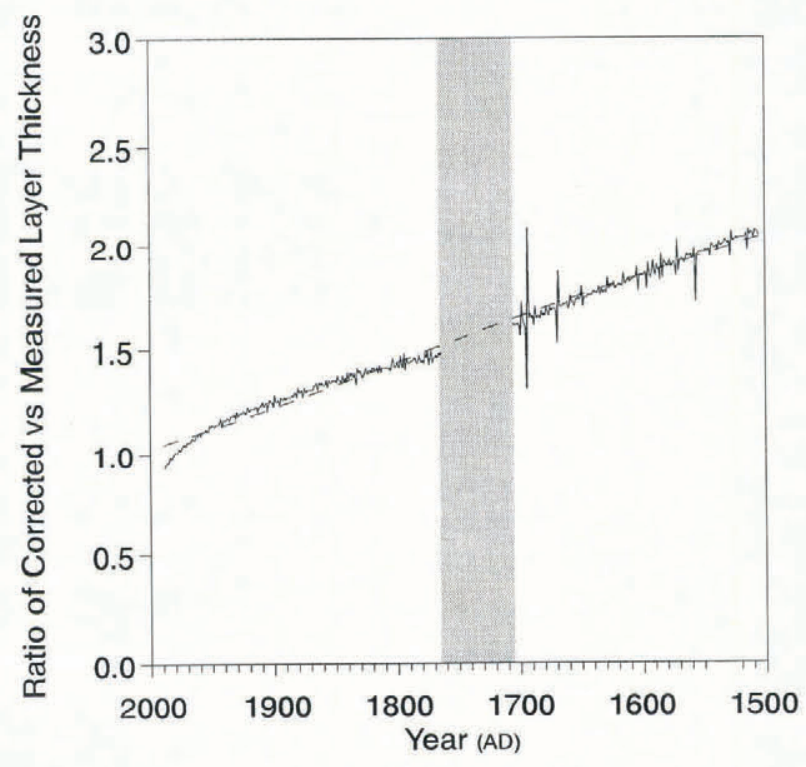

Fig. 3. Ice flow thins the thicknesses of old annual layers. This graph showes the ratios of annual layer thicknesses corrected for thinning over the measured layer thicknesses in cores C1 and C2. The shaded area indicales the poorquality section of the core. The dashed line represents linear regression fil to the data, which is used in the flux calculation for the poor-quality section.

\section{Calculation of nss $\mathrm{SO}_{4}{ }^{2-}$}

On Dyer Plateau, the extremely low concentrations of insoluble dust (Thompson and others, 1994) indicate the lack of continental-dust aerosols in the atmosphere and hence in the snow. This leads to the assumption that the only important source of $\mathrm{Na}^{+}$in snow is sea-salt aerosol; therefore, the non-sea-salt part of $\mathrm{SO}_{4}{ }^{2-}$ in total $\mathrm{SO}_{4}{ }^{2}$ may be estimated this way:

$$
\mathrm{nss} \mathrm{SO}_{4}{ }^{2-}=\mathrm{SO}_{4}{ }^{2-}-R_{\mathrm{Na}} \times \mathrm{Na}^{+}
$$


where $R_{\mathrm{Na}}=0.12$ is the ratio of $\mathrm{SO}_{4}{ }^{2-}$ to $\mathrm{Na}^{+}$in bulk sea water. For the spatial-variability study, where $\mathrm{Na}^{+}$ measurements are available, nss- $\mathrm{SO}_{4}{ }^{2}$ concentrations are calculated according to Equation (1), and are presented in Table 1.

As will be discussed later, the ratios of $\mathrm{Na}^{+}$to $\mathrm{Cl}$ concentrations in snow adhere closely to that of bulk sea water, so it is probable that nearly all $\mathrm{Cl}^{-}$in the snow is derived from sea salt. Consequently, nss $\mathrm{SO}_{4}{ }^{2}$ may be calculated using the $\mathrm{SO}_{4}{ }^{2} / \mathrm{Cl}^{-}$ratio in sea water $\left(R_{\mathrm{Cl}}=0.103\right)$ :

$$
\text { nss } \mathrm{SO}_{4}{ }^{2-}=\mathrm{SO}_{4}{ }^{2-}-\mathrm{R}_{\mathrm{Cl}} \times \mathrm{Cl}^{-} .
$$

Since only anion concentrations were measured in the $181 \mathrm{~m}$ section of cores C1 and C2, Equation (2) is used for nss- $\mathrm{SO}_{4}{ }^{2}$ flux calculations which are in turn employed in the annual time series of nss $\mathrm{SO}_{4}{ }^{2-}$ for the last 485 years.

\section{Flux calculation}

The air-to-ground flux of a chemical species in an ice-core sample is calculated according to:

$$
\begin{aligned}
& \text { FLUX }\left(\mathrm{g} \mathrm{cm}^{-2}\right)= \\
& \text { CONCENTRATION }\left(\mathrm{g} \mathrm{cm}^{-3}\right) \times \operatorname{SAMPLESIZE~}(\mathrm{cm})(3)
\end{aligned}
$$

in which sample sizes represent accumulation in water equivalent. The sum of the fluxes of all samples in an icecore year is the annual flux for that year, or:

$$
F=\sum F_{\mathrm{i}}=\sum\left(C_{\mathrm{i}} \times S_{\mathrm{i}}\right)
$$

where i denotes individual samples in one year.

Annual fluxes of $\mathrm{Cl}^{-}, \mathrm{NO}_{3}$ and nss $\mathrm{SO}_{4}{ }^{2-}$ for the 485 years (1505-1989) contained in the $181 \mathrm{~m}$ core section have been calculated using Equations (3) and (4). Layer thinning affects the annual layer thickness as well as the sample sizes and consequently the calculated fluxes. To compensate for this effect, the annual flux calculated according to Equations (3) and (4) is multiplied by the ratio of the corrected (for thinning) annual layer thickness to the measured thickness, as shown in Figure 3. The thinning-corrected flux data, along with annual accumulation rates, are shown in Figure 4.

\section{DISCUSSION}

\section{Snow chemical composition}

In the first part of this study, core sections from three separate cores/sites are examined for snow chemical composition. The time period under discussion here is the decade 1950 -60. No major volcanic eruptions or other unusual events affecting the atmospheric chemistry of the high southern latitudes were reported in this period. Therefore, the chemical composition of these samples is considered to be representative of the prevalent background snow chemistry in this area.

Average concentrations of the ions measured and other relevant data are presented in Table 1 . It can be seen that $\mathrm{K}^{+}$concentrations are significantly lower than the others and carry a large $(100 \%)$ analytical uncertainty; hence $\mathrm{K}^{+}$is a minor ion in snow. Since no other ions are present in concentrations above the detection limits of the ion chromatography methods (with the exception of $\mathrm{H}^{+}$and $\mathrm{HCO}_{3}^{-}$), Table 1 demonstrates that $\mathrm{Na}^{+}, \mathrm{Cl}, \mathrm{NO}_{3}$ and $\mathrm{SO}_{4}{ }^{2-}$ are the major ionic species in snow. Selected meltwater samples were measured for $\mathrm{pH}$ for a qualitative indication of sample acidity (we are aware of the limitations of $\mathrm{pH}$ measurements of meltwater samples). A mean $\mathrm{pH}$ value of 5.3, with a range of 5.0-5.6, was obtained for a large number $\approx 800)$ of samples. These $\mathrm{pH}$ values suggest that $\mathrm{H}^{+}$probably exists in the snow at concentrations comparable to those of the other major ions.

The ratios of $\mathrm{Na}^{+}$to $\mathrm{Cl}^{-}$concentrations in all snow samples (Table 1) are close to that of bulk sea water (0.86). This suggests that sea-salt aerosols over the Dyer Plateau region have not experienced significant fractionation which would result in lower $\mathrm{Na}^{+} / \mathrm{Cl}^{-}$ratios (Legrand and Delmas, 1988). Together with data from other Antarctic Peninsula locations Mulvaney and Peel. 1988), these results suggest that formation of $\mathrm{HCl}$ from sea salt and atmospheric acids (most probably sulfuric and nitric acids) may be a phenomenon limited to the dry atmosphere of the interior Antarctic continent (Legrand and Delmas, 1988).

Among the cations measured here, only $\mathrm{H}^{+}$and $\mathrm{Na}^{+}$ have concentrations comparable to those of the major anions $\left(\mathrm{Cl}, \mathrm{SO}_{4}{ }^{2}\right.$ and $\left.\mathrm{NO}_{3}{ }^{-}\right)$. As discussed previously, the only major source of $\mathrm{Na}^{+}$and $\mathrm{Cl}$ is probably sea salt. Since all cations and anions in sea salt must balance ionically, this leaves the non-sea-salt major anions $\left(\mathrm{nss} \mathrm{SO}_{4}{ }^{2}\right.$ and $\mathrm{NO}_{3}$ ) to balance the only other cation, $\mathrm{H}^{+}$. This leads to the conclusion that the principal chemical compounds from non-sea-salt sources are $\mathrm{HNO}_{3}$ and $\mathrm{H}_{2} \mathrm{SO}_{4}$, consistent with results of snow chemistry studies in other parts of Antarctica (e.g. Legrand and Delmas, 1984).

\section{Spatial variation of chemistry on Dyer Plateau}

Local spatial variations in snow chemistry are important when long-term changes in atmospheric composition over a large area are to be inferred from a single ice-core record. Knowledge of local variability helps in the selection of ice-core drilling sites that are most representative of the location. As part of a survey program to identify a deep ice-coring site, several shallow $(50 \mathrm{~m})$ and intermediate $(100-235 \mathrm{~m})$ cores were drilled in the Dyer Plateau area. The ionic concentrations in three cores across the ice divide are used to assess the spatial variability of the snow chemistry.

When comparing cores from closely located sites, it makes little sense to try to match individual samples since it is impossible to obtain snow samples deposited simultaneously, except perhaps when snow samples are collected in situ during a precipitation event. Even specific years in separate ice cores are difficult to compare, for the definition of the length (or the number of samples) of an ice-core "year" is somewhat arbitrary and the comparison may not be between the same lengths of the "year", given the finite number of samples in a year, even if the same "year" is being evaluated. Thus, 

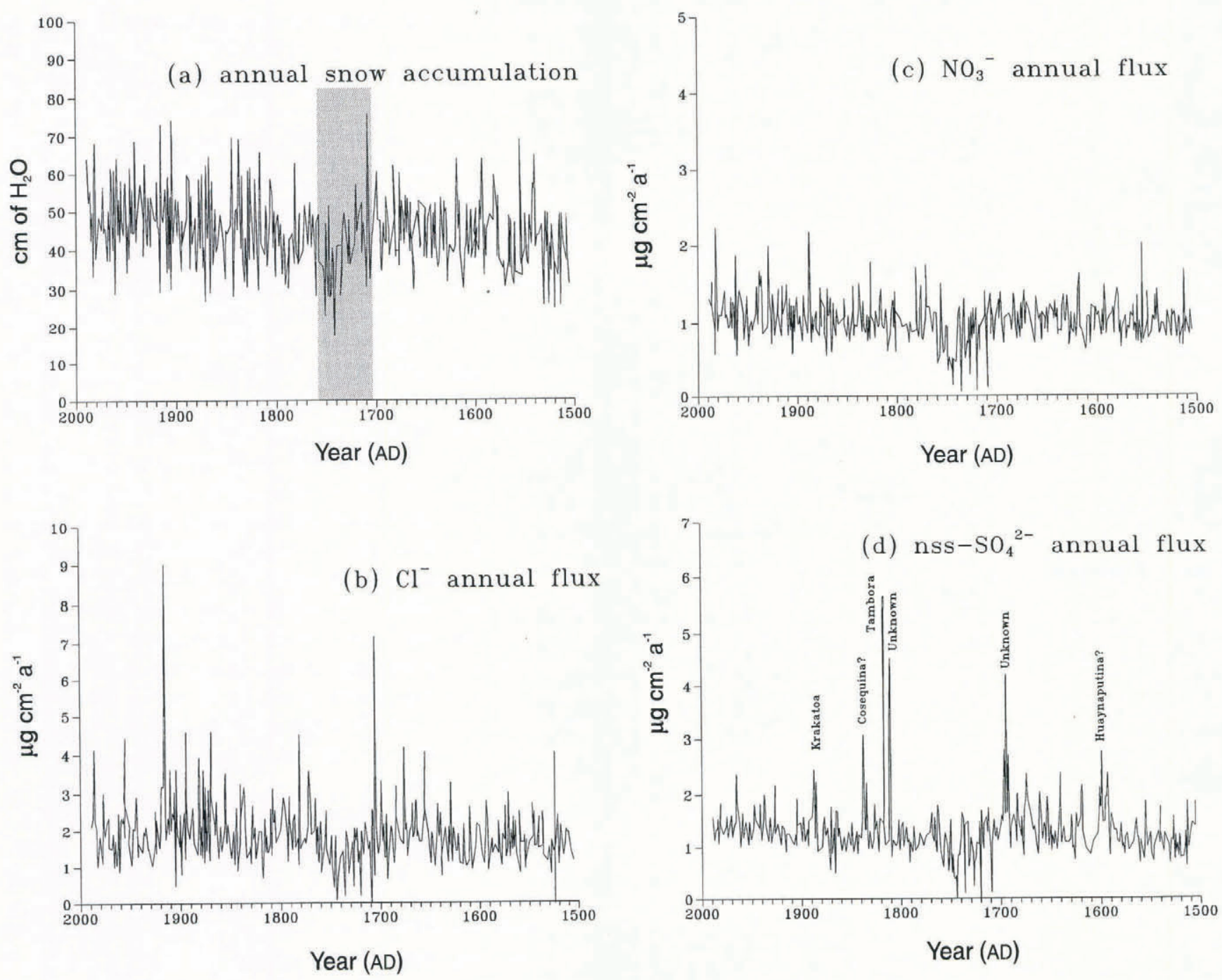

Fig. 4. Cubic-spline smoothed dala are shown for (a) annual accumulation rates, and fluxes of (b) $\mathrm{Cl},(c) \mathrm{NO}_{3}{ }^{-}$and (d) nss $\mathrm{SO}_{4}{ }^{2-}$ for the past 485 years. The shaded area in (a) indicates the poor-quality section of the core, where accumulation rates may be underestimated. The identification of prominent volcanic events in $(d)$ is based on dating and comparison with a similar record from Siple Station (Mosley-Thompson and others, 1991).

sections spanning several years are necessary for appropriate comparison. In the three columns of Table 1, the average ionic concentrations of each core section are listed for the three sites. Six to seven complete sulfate and $\delta^{18} \mathrm{O}$ cycles (years) are contained in each section with assigned dates. Since the core sections were selected assuming similar accumulation rates at all three sites, which are quite different (see Table 1), they correspond to different time intervals (Table 1, row 3 ). Nonetheless, the large number of samples in each section ensures that comparison between the sections or the sites can be made using average concentrations and variances.

The average concentrations of all ions and $\mathrm{Na}^{+} / \mathrm{Cl}$ ratios show rather small differences among the sites (Table 1), even with the somewhat different 6 year periods covered by the three core sections. These small variances indicate that there is no directional preference for the deposition of the ions, including the sea-salt aerosols. The exceptionally small variance of nss $\mathrm{SO}_{4}{ }^{2-}$, coupled with the fact that its seasonal cycles are very regular, strongly suggests that deposition of this species is a large-scale atmospheric process and that there is little local influence on or postdepositional alteration of its signal in snow.

\section{Accumulation and flux in the last 485 years}

As discussed elsewhere (Thompson and others, 1994), Figure 4 a shows that the net snow-accumulation rate on Dyer Plateau is relatively stable over the last five centuries. Nonetheless, several trends are discernible in the 485 year record. First, the accumulation rates between AD 1700 and 1750 (Fig. 4a; shaded area) fall well below the 485 year average. As discussed above, the core quality in this section is rather poor, which casts doubt on the validity of the reduced accumulation rate. Results from other Dyer cores currently under analysis may confirm or refute this period of low accumulation. However, strong positive cross-correlation with the Siple Station accumulation record (Thompson and others, 1994) suggests that the low net accumulation at this time period may not be a spurious event, but may be more spatially extensive (Thompson and others, 1994). Secondly, a small, gradual increase in net annual accumulation rate begins in the late 19th century and lasts to the present. Over this interval the annual accumulation increases from an average of 43 to about $52 \mathrm{~cm}$ w.e. $\mathrm{a}^{-1}$. Similar increases in other ice-core records from the Antarctic Peninsula 
indicate that the trend may be widespread in the region (Thompson and others, 1994).

This small increase in annual accumulation since the late 19th century may account for the concurrent slight increase in the $\mathrm{NO}_{3}{ }^{-}$and nss- $\mathrm{SO}_{4}{ }^{2}$ fluxes in the same time period (Fig. 4). No trend is apparent in $\mathrm{Cl}$. From 1700 to 1760 , all three anion species exhibit belowaverage fluxes; however, this probably reflects the loss of ice in this section of the core (zero concentration and flux for lost ice).

Among the three anions, $\mathrm{Cl}^{-}$shows the largest temporal variability, which suggests that sea-salt deposition reflects the sporadic intrusion into the Dyer Plateau area of synoptic air masses containing sea-salt aerosols. The nitrate flux is relatively constant for the entire time period, as the largest annual $\mathrm{NO}_{3}$ fluxes are only twice the average. This implies that the sources of $\mathrm{NO}_{3}$ in the atmosphere are probably quite stable from year to year and on the time-scale of centuries. It is also clear that the deposition of $\mathrm{NO}_{3}{ }^{-}$is not significantly affected by fluctuations in local meteorological conditions. The nss$\mathrm{SO}_{4}{ }^{2}$ flux profile is characterized by large peaks $2-5$ times above the background level. These peaks represent several known and suspected volcanic eruptions in the last 485 years (Thompson and others, 1994), as indicated in Figure $4 \mathrm{~d}$. A detailed discussion of the nss- $\mathrm{SO}_{4}{ }^{2}$ volcanic chronology will be presented elsewhere.

\section{Dry vs wet deposition of anions}

An examination of the relationship between the net accumulation rate and the ionic flux may reveal characteristics of the processes by which specific atmospheric chemical species are deposited on to the snow surface (Davidson, 1989). An atmospheric constituent, as either particulate or gaseous aerosols, may be incorporated into or scavenged by water droplets or snow grains and be deposited as a direct result of precipitation wet deposition); or the atmospheric species may fall without accompanying precipitation (dry deposition). In the case of wet deposition, the flux can be expected to be proportionally related to the amount of precipitation or accumulation. Conversely, the flux by dry deposition should be independent of the accumulation rate. Thus, the relationship between flux and accumulation may be described simply as

$$
F=F_{\mathrm{d}}+F_{\mathrm{w}}=F_{\mathrm{d}}+b A_{\mathrm{n}}
$$

where $F_{\mathrm{d}}$ and $F_{\mathrm{w}}$ represent dry- and wet-deposition flux, respectively. $A_{\mathrm{n}}$ is the snow-accumulation rate. The parameter $b$ is related to the scavenging efficiency of an atmospheric species by precipitation and should be constant under given atmospheric conditions. If the flux plotted as a function of accumulation is a straight line, the intercept of the line should be the dry-deposition part of the flux. A positive slope of the straight line would indicate that the deposition is dependent on precipitation (wet deposition).

The annual fluxes of $\mathrm{Cl}, \mathrm{NO}_{3}{ }^{-}$and nss $\mathrm{SO}_{4}{ }^{2-}$ are plotted in Figure 5 as functions of the annual net accumulation rate reconstructed from the layer thicknesses. Because flux is calculated as the product of both
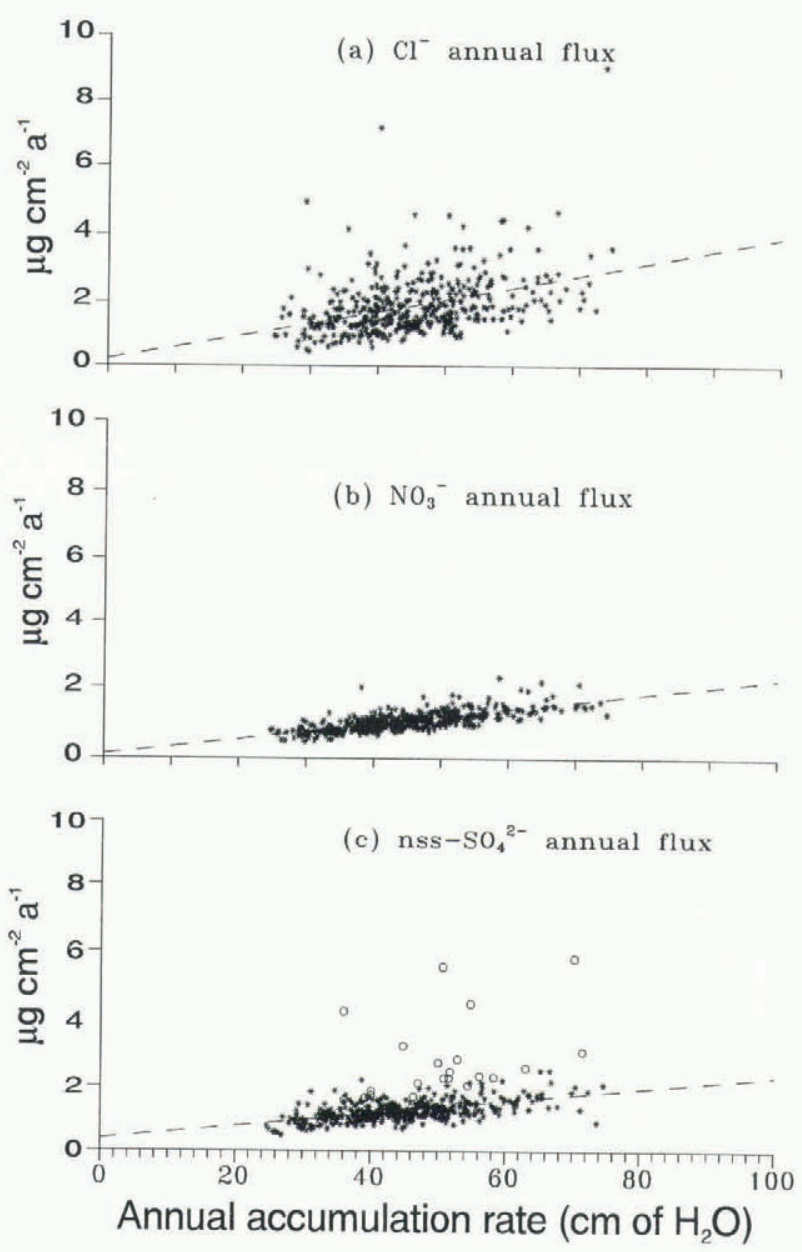

Fig. 5. Annual fluxes of (a) $\mathrm{Cl}$, (b) $\mathrm{NO}_{3}{ }^{-}$and (c) niss $\mathrm{SO}_{4}{ }^{2-}$ are shown as functions of annual net accumulation. Flux (in $\mu_{\mathrm{g} \mathrm{cm}} \mathrm{c}^{-1}$ ) and accumulation data for the period $1706-63$ were removed from the data set due to poor core quality. Circles in $(c)$ represent known and suspected volcanic years and the dashed lines are linear-regression fits to "*" data.

concentration and accumulation, there is a tendency for the slope to be positive. The dashed lines in Figure 5 represent the least-square linear fits to the data.

All three linear fits exhibit positive slopes, suggesting that the deposition of all three species is somewhat dependent on precipitation. However, there are significant differences among the plots. For example, the linear regression line for $\mathrm{NO}_{3}$ shows the best fit to the data the correlation coefficient is 0.74 ; see Table 2 ). This is a strong indication that $\mathrm{HNO}_{3}$ aerosols serve as efficient condensation nuclei or that they are efficiently scavenged by precipitation. The linear fit to $\mathrm{NO}_{3}$ flux has the smallest intercept $\left(0.103 \mu \mathrm{g} \mathrm{cm}^{-2} \mathrm{a}^{-1}\right)$, suggesting that dry deposition contributes less than $10 \%$ of the average $\mathrm{NO}_{3}$ flux $\left(1.06 \mu \mathrm{g} \mathrm{cm}^{2}\right)$ deposited annually.

Sea-salt aerosols are generated by bursting bubbles of ocean spray. In Antarctica, most airborne sea-salt aerosol quickly settles along the coastal areas due to gravity (Legrand and Delmas, 1985). Dried sea-salt aerosol particles in the dry Antarctic atmosphere are not considered good condensation nuclei; therefore, the amount of $\mathrm{Cl}$ in snow is not expected to be strongly dependent on accumulation rate. As expected, the $\mathrm{Cl}$ 
Table 2. Statistical summary of the annual net accumulation and flux dala, as illustrated in Figure 5. Data for 1706-63 are excluded, due to the probable loss of core during drilling. Values in parentheses are obtained after conspicuous volcanic years are removed from the data set

$$
\text { Average } \delta^{\#} \quad \text { Linear regression vs accumulation }
$$

\begin{tabular}{llllll}
\hline $\begin{array}{l}\text { Accumulation } \\
\left(\mathrm{cm} \mathrm{H}_{2} \mathrm{O} \mathrm{a}^{-1}\right)\end{array}$ & 44.9 & 9.69 & & & \\
$\begin{array}{l}\text { Chloride } \\
\left(\mu \mathrm{g} \mathrm{cm}^{-2} \mathrm{a}^{-1}\right)\end{array}$ & 1.33 & 0.54 & 0.03 & 0.21 & 0.41 \\
& & & $(0.04)$ & $(0.19)$ & $(0.41)$ \\
Nitrate & 1.06 & 0.28 & 0.02 & 0.10 & 0.74 \\
& & & $(0.02)$ & $0.09)$ & $(0.74)$ \\
Nss sulfate & 1.88 & 0.87 & 0.02 & 0.20 & 0.45 \\
& & & $(0.02)$ & $0.38)$ & $0.56)$ \\
& & & & & \\
\hline
\end{tabular}

\# Standard deviation.

* Correlation coefficient.

data show a large scatter in Figure $5 \mathrm{a}$ and the correlation between $\mathrm{Cl}^{-}$flux and accumulation is rather poor $(r=0.42)$. In fact, even the weak correlation may reflect the bias toward a positive correlation resulting from the flux calculation, as discussed above.

The case of nss $\mathrm{SO}_{4}{ }^{2}$ is more complicated than the other two species. Although the nss- $\mathrm{SO}_{4}{ }^{2}$ flux, similar to $\mathrm{Cl}^{-}$, appears to be poorly correlated with accumulation $(r=0.45$; Table 2$)$, it is probable that large inputs from explosive volcanic sources distort the normal nss-SO ${ }_{4}{ }^{2}$ deposition-accumulation relationship. When years with high nss- $\mathrm{SO}_{4}{ }^{2-}$ fluxes from known and suspected volcanic eruptions are removed from the data set, the correlation between the remaining nss- $\mathrm{SO}_{4}{ }^{2-}$ flux and accumulation is significantly improved, with $r$ increasing from 0.45 to 0.56 (Table 2 ). By contrast, removal of the volcanic years does not result in a significant change in either the $\mathrm{NO}_{3}$ or $\mathrm{Cl}$ regression results (Table 2 ). The $\mathrm{nss}_{-} \mathrm{SO}_{4}{ }^{2}$ intercept also increases from 0.20 to $0.38 \mu \mathrm{g} \mathrm{cm}^{-2} \mathrm{a}^{-1}$ with the removal of volcanic years. This would mean that in non-volcanic years, only $25 \%$ or $0.38 \mu \mathrm{g} \mathrm{cm}^{-2} \mathrm{a}^{-1}$ of the nss-SO ${ }_{4}^{2-}$ flux (average: $1.88 \mu \mathrm{g} \mathrm{cm}^{-2} \mathrm{a}^{-1}$ ) may be attributed to dry deposition.

\section{GONCLUSIONS}

The snow chemistry on Dyer Plateau is dominated by the presence of $\mathrm{NaCl}$ from sea-salt aerosol, and nitric and sulfuric acids from gaseous atmospheric aerosols. The local spatial variability in snow chemistry is remarkably small and the temporal variations are well preserved in shallow and intermediate ice cores; therefore, excellent and spatially representative records can be expected from future deep ice cores. At this location, sulfuric and nitric acids are deposited mainly by wet processes (cloud condensation and scavenging). In contrast, the $\mathrm{Cl}$ deposition, most probably associated with sea-salt aerosol particles, is largely independent of precipitation.

The annual time series of $\mathrm{Cl}^{-}, \mathrm{NO}_{3}{ }^{-}$and nss $\mathrm{SO}_{4}{ }^{2}$ from AD 1505 to 1989 show no significant trends. Thus, the Dyer Plateau record is consistent with previous icecore-derived histories (Delmas, 1992) which indicate no significant anthropogenically produced atmospheric pollution in the high latitudes of the Southern Hemisphere.

\section{ACKNOWLEDGEMENTS}

We thank the personnel at the Byrd Polar Research Center (BPRC) and the British Antarctic Survey who participated in the field program and B. Koci of the Polar Ice Coring Office, which is supported by the U.S. National Science Foundation. P.-N. Lin and M. Davis of BPRC contributed to the laboratory analyses of the ice cores. We thank R. Mulvaney of the British Antarctic Survey for his contributions, C. Raymond of the University of Washington for providing layer-thinning data, and two anonymous reviewers for their constructive comments. The project was supported by NSF Grants DPP8716384 and ATM-90084-7 to The Ohio State University. This is contribution No. 912 of the BPRC.

\section{REFERENCES}

Davidson, C. I. 1989. Mechanisms of wet and dry deposition of atmospheric contaminants to snow surface. In Oeschger, H. and C. C. Langway, Jr, eds. The environmental record in glaciers and ice sheets. Chichester, etc., John Wiley and Sons, 29-51.

Delmas, R.J. 1992. Environmental information from ice cores. Rev. Geophys., 30 1), 1-21.

Legrand, M. R. and R. J. Delmas. 1984. The ionic balance of Antarctic snow: a 10-year detailed record. Atmos. Emviron., 18 9), 1867-1874.

Legrand, M. and R. J. Delmas. 1985. Spatial and temporal variations of snow chemistry in Terre Adélie (East Antarctica). Amn. Glaciol., 7, $20-25$.

Legrand, M.R. and R.J. Delmas. 1988. Formation of $\mathrm{HCl}$ in the Antarctic atmosphere. J. Geophys. Res., 93 (D6), 7153-7168.

Mosley-Thompson, E., J. Dai, L. G. Thompson, P. M. Grootes, J. K. Arbogast and J.F. Paskievich. 1991. Glaciological studies at Siple Station Antarctica): potential ice-core paleoclimatic record. $j$. Glaciol., 37 (125), 11-22.

Mulvaney, R. and D. A. Peel, 1988. Anions and cations in ice cores from Dolleman Island and the Palmer Land plateau, Antarctic Peninsula. Ann. Glaciol., 10, 121-125.

Saigne, C., S. Kirchner and M. Legrand. 1987. Ion-chromatographic measurements of ammonium, fluoride, acetate, formate, and methanesulphonate ions at very low levels in Antarctic ice. Anal. Chim. Acta, 203 1), 11-21.

Shaw, G.E. 1989. Aerosol transport from sources to ice sheets. In Oeschger, H. and C. C. Langway, Jr, eds. The environmental record in glaciers and ice sheets. Chichester, etc., John Wiley and Sons, 1327.

Thompson, L. G., E. Mosley-Thompson, J. F. Bolzan and B. R. Koci. 1985. A 1500-ycar record of tropical precipitation in ice cores from the Quelccaya ice cap, Peru. Science, 229 4717), 971-973.

Thompson, L. G. and 7 others. 1994. Climate since AD 1510 on Dyer Plateau, Antarctic Peninsula: evidence for recent climate change. Ann. Glaciol, 20, 420-426.

Wagenbach, D., U. Görlach, K. Moser and K.O. Münnich. 1988. Coastal Antarctic aerosol: the seasonal pattern of its chemical composition and radionuclide content. Tellus, 40B, 426-436. 